\title{
マルテンサイト系ステンレス鋼における $M_{\mathrm{s}}$ 点 予測モデルの妥当性に関する実験的検証
}

\author{
中川 英樹* ·宮崎 亨*2
}

Experimental Examination of the Validity of the Model for Predicting $M_{s}$ Temperature for Martensitic Stainless Steels

Hideki NAKAgAWA and Toru MIYAZAKI

Synopsis : Comparisons between the experimentally measured $M_{s}$ and the calculated $M_{s}$ temperatures for eleven martensitic stainless steels were performed on the basis of conventional models.

Empirical formulae for the calculation of $M_{s}$ temperature do not show enough ability to predict the $M_{s}$ temperature of all martensitic stainless steels, i.e. available alloying elements and their composition ranges are restricted. While, the Ghosh and Olson model for the prediction of $M_{s}$ temperature is shown to be reasonably good in estimating the $M_{s}$ temperature for martensitic stainless steels except some conditions.

Key words: $M_{s}$ temperature; martensitic transformation; stainless steel; electric resistance; grain size.

\section{1. 緒言}

鋼の $M_{4}$ 点を知ることは，材料開発や製造工程を決定す るうえで大変に重要である。このような背景から， $M_{s}$ 点 を予測する試みがなされ，これまでに低合金鋼からステン レス鋼などの高合金鋼に至るまで，数多くの $M_{\text {点予測式 }}$ が提案されている(-8)。しかしながら，これらの予測式は，

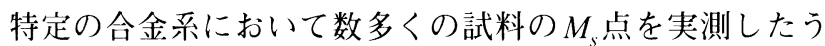
えで，主要な合金元素を独立変数とする重回帰分析などに より定式化されている。そのため，考慮されている合金元 素の種類が限られている。また，その適用は実験で考慮さ れた成分範囲に限定されてしまう

一方, $M_{s}$ 点を実験結果の解析からではなく, 熱力学的 見地から予測する試みも提案されている ${ }^{9-12) 。 G h o s h と ~}$ Olson $^{12)}$ は，マルテンサイト変態が開始するための臨界駆 動力 $\Delta G M_{\vee}$ が，マルテンサイト相生成に伴って発生するひ ずみエネルギーと界面エネルギ一，および界面移動に対す る各添加元素の固溶強化効果の総和として与えられるとい う考えに基づき， $\Delta G M_{v}$ が 14 種類の合金元素を独立変数と する関数で表されることを示している。そして，フェライ 卜相とオーステナイト相の自由エネルギー差 $\Delta G_{b c c-f c c}$ が， $\Delta G M_{s}$ と等しくなる温度を $M_{s}$ 点として予測できると報告し ている。このような手法により適切な予測がなされるなら ば，上記の問題は解消され，非常に有効な $M_{s}$ 点予測の手 段になると考えられる。

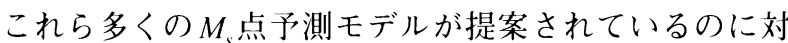

し，これらを検証しようとする試みは以外にも少な (1,13-15)。規格鋼などの実用材料，中でも高合金であるス テンレス鋼に関する報告は非常にわずかである。

そこで本研究では，沉用のマルテンサイト系ステンレス 鋼およびマルテンサイト系析出硬化型ステンレス鋼を供試 材として，実験的に $M_{s}$ 点を測定したうえで，いくつかの 予測式およびGhoshとOlsonのモデルより導かれる $M_{s}$ 点と 実測值の比較を行い，それらの有効性を検証することを目 的とする。

\section{2. 供試材および実験方法}

\section{$2 \cdot 1$ 供試材}

マルテンサイト系ステンレス鋼 6 種類およびマルテンサ イト系析出硬化型ステンレス鋼 5 種類を供試材とした。供 試材の組成を Table 1 に示す。供試材の中でNo. 5 が最も高 いC濃度を有する。また， No. 6 は Fe- $16 \mathrm{Cr}-5 \mathrm{Ni}-1 \mathrm{Mn}-1 \mathrm{Mo}$ 系のマルテンサイト系ステンレス鋼である。No. 7〜10 は C および Nb濃度を変化させた 4 種類のSUS630 系析出硬化型 ステンレス鋼である。さらに，No.11 は残留オーステナイ

ト含有型の析出硬化型ステンレス鋼である ${ }^{16) 。}$

これら供試材は, 棒状または板状の圧延材もしくは熱処 理材として入手し，熱間圧延により板厚 $3 \sim 5 \mathrm{~mm}$ の板状試 料とした後，冷間圧延により板厚 $0.7 \mathrm{~mm}$ に仕上げ，供試 材とした。

平成 10 年 8 月 27 [1受付 平成 10 年1 0 月 27 月受理 (Received on Aug. 27, 1998; Accepted on Oct. 27, 1998)

* 名古屋 L. 業大学大学院生. (Graduate Student, Nagoya Institute of Technology, Gokiso-cho Showa-ku Nagoya 466-8555); 愛知製鋼（株) 第 1 開発部 (Development Div. No.1, Aichi Steel Corporation)

*2 名古屋工業大学 (Nagoya Institute of Technology) 
Table 1. Chemical composition (mass $\%$ ) and $T_{1}$ temperature of specimens used in this work.

\begin{tabular}{|c|c|c|c|c|c|c|c|c|c|c|c|c|}
\hline No. & $\mathrm{C}$ & $\mathrm{Si}$ & $\mathrm{Mn}$ & $\mathrm{Cu}$ & $\mathrm{Ni}$ & $\mathrm{Cr}$ & $\mathrm{Mo}$ & $\mathrm{Al}$ & $\mathrm{N}$ & $\mathrm{Nb}$ & $\mathrm{T}_{1}(\mathrm{~K})$ & Standard \\
\hline 1 & 0.130 & 0.30 & 0.42 & 0.10 & 0.17 & 11.62 & 0.099 & 0.002 & 0.011 & ---- & 1248 & SUS403 \\
\hline 2 & 0.152 & 0.38 & 0.66 & 0.09 & 1.69 & 15.30 & 0.133 & 0.001 & 0.032 & ---- & 1298 & SUS431 \\
\hline 3 & 0.134 & 0.29 & 0.91 & 0.14 & 0.17 & 12.13 & 0.085 & 0.002 & 0.012 & ---- & 1248 & SUS416 \\
\hline 4 & 0.300 & 0.50 & 0.42 & 0.09 & 0.21 & 12.06 & 0.073 & 0.001 & 0.014 & ---- & 1223 & SUS420J2 \\
\hline 5 & 0.618 & 0.29 & 0.68 & 0.03 & 0.10 & 12.76 & 0.008 & 0.026 & 0.014 & ---- & 1323 & ---- \\
\hline 6 & 0.035 & 0.43 & 0.98 & 0.15 & 4.70 & 15.66 & 0.950 & 0.006 & 0.058 & ---- & 1313 & $\cdots$ \\
\hline 7 & 0.030 & 0.33 & 0.71 & 3.23 & 4.70 & 15.50 & 0.000 & 0.006 & 0.013 & 0.02 & 1313 & \multirow{2}{*}{ SUS630 } \\
\hline 8 & 0.026 & 0.25 & 0.49 & 3.60 & 4.80 & 15.76 & 0.049 & 0.006 & 0.012 & 0.16 & 1313 \\
\hline 9 & 0.056 & 0.35 & 0.73 & 3.23 & 3.89 & 15.63 & 0.100 & 0.004 & 0.027 & 0.25 & 1313 & series \\
\hline 10 & 0.043 & 0.35 & 0.76 & 3.25 & 4.61 & 15.42 & 0.020 & 0.004 & 0.019 & 0.39 & 1313 & \\
\hline 11 & 0.008 & 0.21 & 0.28 & 1.78 & 7.29 & 15.91 & 1.159 & 0.023 & 0.017 & 0.08 & 1273 & $\ldots$ \\
\hline
\end{tabular}

\section{$2 \cdot 2$ 実験方法}

$M_{s}$ 点の測定には電気抵抗測定装置を用いた。供試材を 幅 $3.5 \mathrm{~mm}$, 長さ $40 \mathrm{~mm}$ に切り出し, Table 1 に示す温度 $T_{1}$ で $1.2 \mathrm{ks}$ 空冷の前処理を行った後，電気抵抗測定に供した。 電気抵抗測定では, 定電流 $300 \mathrm{~mA}$ のと, 直流 4 端子法 により温度に対する電圧変化を測定し, その電圧変化曲線 から $M_{s}$ 点を決定した。電気抵抗測定時の熱処理条件は, 窒温から温度 $T_{1}$ まで $600 \mathrm{~s}$ で昇温し， $T_{1}$ で $1.2 \mathrm{ks}$ 保持した後， 空冷とした。なお, 前処理および電気抵抗測定はすべて真 空中で実施した。また, 測定後の試料を用いて, 光学顕微 鏡および走査型電子顕微鏡による組織観察を行った。さら に, 一部の試料では, 前処理条件を変化させて $M_{s}$ 点の測 定を尖施した。

\section{3. 実験結果および考察}

\section{$3 \cdot 1 M_{s}$ 点の測定結果}

Fig. 1(a)に供試材No. 9の降温過程における500３00Kの 電庄変化曲線を示す。オーステナイト化温度 $1313 \mathrm{~K}$ から, 温度の低下に伴って電压は単調に減少するが, $380 \mathrm{~K}$ 付近 を境に急激に上昇していることがわかる。この電压の上昇 はマルテンサイト変態に起因するものであり, Fig. 1(a)に 示すように，高温域の接線からのずれが生じる温度 $402 \mathrm{~K}$ を $M_{s}$ 点として夷測した。供試材No. 6, 7,8,10,11において も、Fig. 1(a)と同様に、マルテンサイト変態に伴う急激な 電圧変化が観察され， $M_{s}$ 点を測定することができた。

Fig. 1(b)に供試材No. 3の降温過程における 650 500Kの 電圧変化曲線を示す。本供試材においても，マルテンサイ 卜変態に伴う電圧変化が検出されているが, その変化量は Fig. 1(a)に比較してかなり小さいことがわかる。同様に高 温側から接線を引き， $M_{s}$ 点を $583 \mathrm{~K}$ と決定した。供試材 No. 1 およびNo. 4においても，マルテンサイト変態に伴っ て Fig. 1(b) と同程度の電圧変化が観察され， $M_{s}$ 点を測定す ることができた。また，供試材No. 2においては，Fig. 1(a) と Fig. 1(b)の中間的な変化量が観察され， $M_{s}$ 点を測定する ことができた。

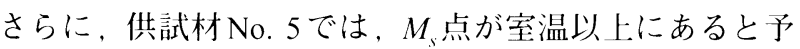
測されるにもかかわらず, 温度の低下に伴って電庄は単調
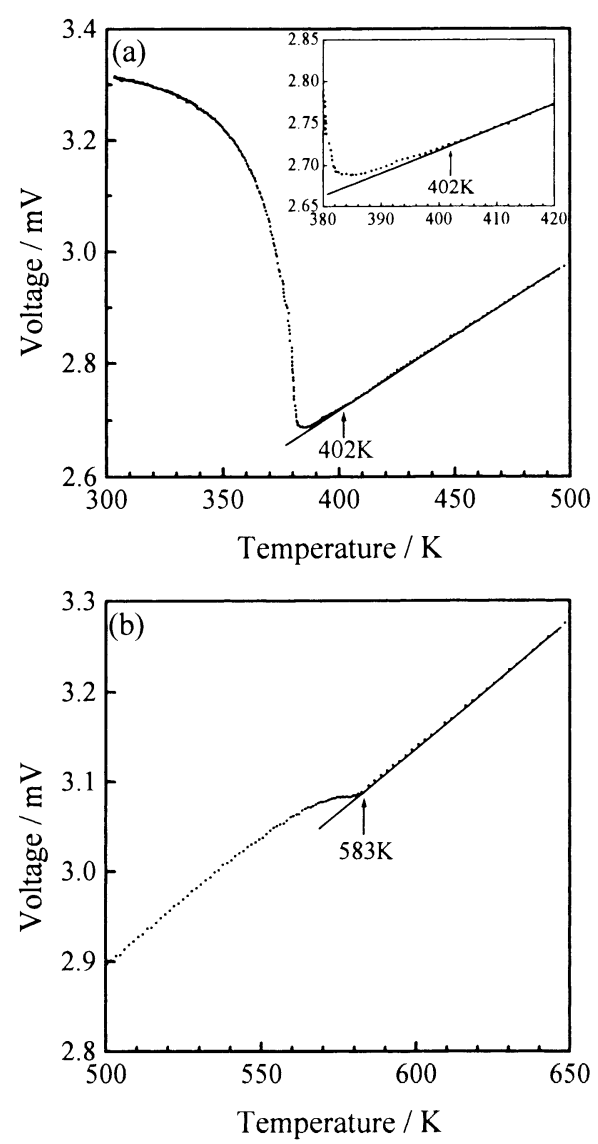

Fig. 1. Voltage changes of (a) specimen No. 9 and (b) specimen No. 3 with air cooling.

に減少するのみであり， $M_{s}$ 点を検出することができなか つた。

マルテンサイト変態に伴う電圧の変化は, マルテンサイ ト相とオーステナイト相の温度に対する電気抵抗の相違に より現れるものである。前述の実験結果から，Cr濃度の 減少およびC濃度の増加に伴い，両相の電気抵抗差が小さ くなるものと判断できる。したがって，对物用ステンレス 鋼や軸受用ステンレス鋼などに用いられる高炭素ステンレ ス鋼の $M_{s}$ 点の測定に対しては，電気抵抗測定は有用でな いといえる

以上の測定により得られた各供試材の $M_{s}$ 点を Table 2 に まとめて示す。なお， $M_{s}$ 点の測定は各供武材で2ヶずつ行 っているが，両者に大きな差は見られない 
Table 2. Measured $M_{\mathrm{s}}$ temperatures of all specimens.

\begin{tabular}{|c|c|}
\hline No. & $\mathrm{M}_{\mathrm{s}}$ Temperature $(\mathrm{K})$ \\
\hline 1 & $599, \quad 599$ \\
\hline 2 & $469, \quad 469$ \\
\hline 3 & $580, \quad 583$ \\
\hline 4 & $593, \quad 584$ \\
\hline 5 & not detected \\
\hline 6 & $395, \quad 403$ \\
\hline 7 & $430, \quad 427$ \\
\hline 8 & $392, \quad 388$ \\
\hline 9 & $396, \quad 402$ \\
\hline 10 & $401, \quad 396$ \\
\hline 11 & $325, \quad 324$ \\
\hline
\end{tabular}
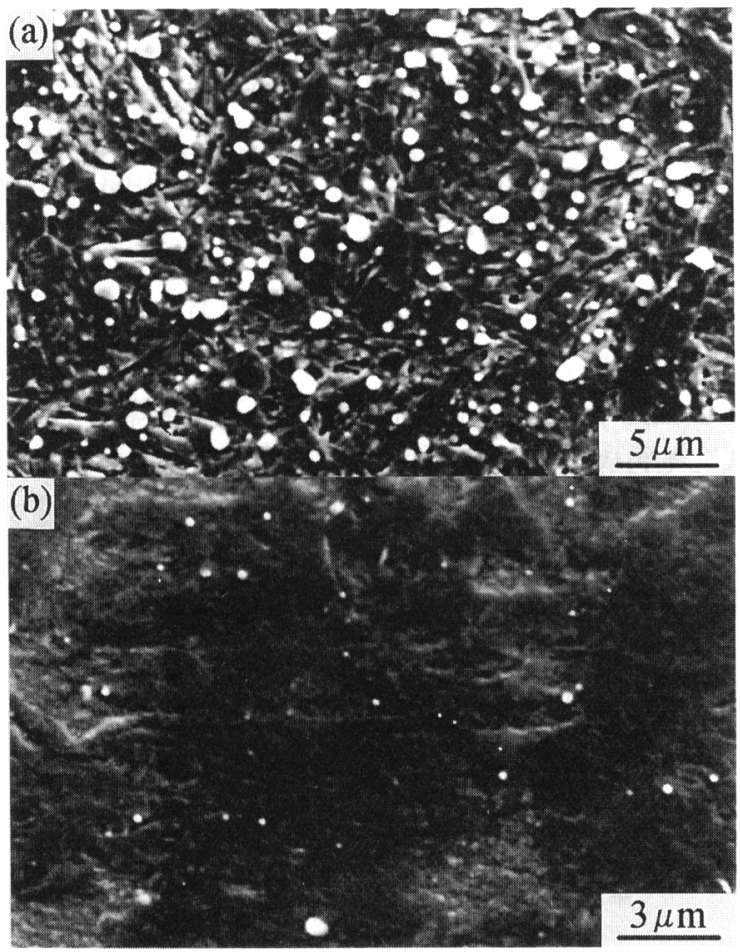

Fig. 2. Scanning electron micrographs of (a) specimen No. 4 and (b) specimen No. 9.

\section{$3 \cdot 2$ 組織観察結果}

$M_{s}$ 点が測定された試料について組織観察を行つた。Fig. 2 に供試材No. 4 およびNo. 90 走査型電子顕微鏡観察結果 を示す。また，走査型電子顕微鏡に装備されたEDS装置 により，炭化物の種類を同定した。No. 4 ではCr系炭化物 が多数観察されている。No. 4 はC 濃度が高いことから， これらはオーステナイト化状態に打いて溶け込みを完了し ていないCr系炭化物であると考えられる。一方，No.9で はNb系炭化物が分散している様子が観察される。供試材 No. 8，10に打いても同様に，Nb系炭化物が観察された。 これらは溶解度積 ${ }^{17)}$ から考えて, オーステナイト化処理 時に析出したものと考えられる。

光学顕微鏡観察により, 供試材No. 3 では圧延方向に伸 びた Mn 系硫化介在物が観察された。これは快削元素とし てSが添加されているためである。また，供試材 No. 8， 9,10 では $\delta$ フライト相が観察されたが，その量は $2 \%$ 以

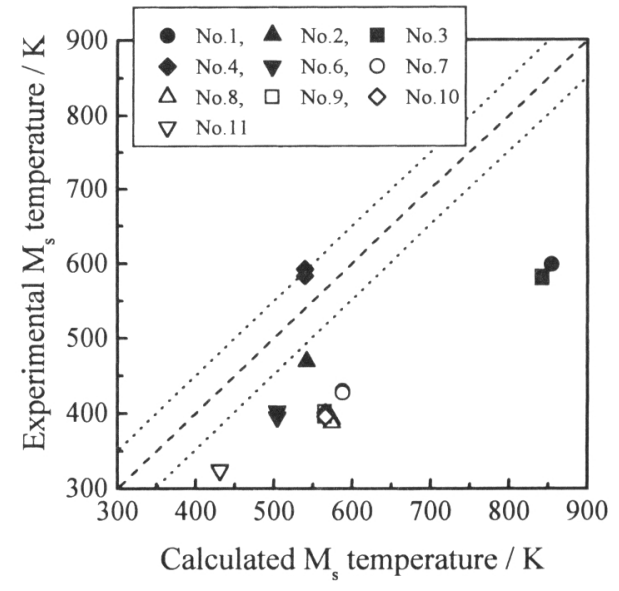

Fig. 3. Comparison between the $M_{\text {s }}$ temperature calculated by Eichelman et al. model and the experimental $M_{s}$ temperature.

下とわすかであった。これは加熱と圧延を多数回繰り返し たためと考えられる。そのほかは特に組織的な特徵はなく, いわゆる正常なマルテンサイト組織が観察された。

\section{4. 考察}

\subsection{Eichelman et al. のモデルおよび Finkler et al. のモ デル}

Eichelman と Hull ${ }^{4}$ は， $\mathrm{Fe}-\mathrm{Cr}-\mathrm{Ni}-\mathrm{Mn}-\mathrm{Si}-\mathrm{C}-\mathrm{N}$ 系において， 25 種類の試料の $M_{s}$ 点を夹測し, 次のような $M_{s}$ 点予測式を 提案している。

$$
\begin{aligned}
M_{s}\left({ }^{\circ} \mathrm{F}\right)= & 75(14.6-\mathrm{Cr})+110(8.9-\mathrm{Ni})+60(1.33-\mathrm{Mn}) \\
& +50(0.47-\mathrm{Si})+3000(0.068(\mathrm{C}+\mathrm{N}))\left(\operatorname{mass}^{0} \%\right) \cdots(1)
\end{aligned}
$$

また，この式の適用成分範井は10〜18 mass \% Cr, 6 12 mass $\%$ Ni, 0.6 5.0 mass\% Mn, 0.3 2.6 mass\% Si, 0.004 0.12 mass\% C および $0.01 \sim 0.06$ mass \% Nとしている。本実 験結果とこの Eichelman et al.のモデルによる計算結果を比 較して Fig. 3 に示す。ほとんどの供試材において, 計算值 が実測值に比べて 50 250K高く， $M_{s}$ 点が適切に予測され ているとは言い難い。これは(1)式に考慮されていない $\mathrm{Cu}, \mathrm{Mo}$ および $\mathrm{Nb}$ が添加されている供試材やNiが添加され ていない供試材があるなど, ほとんどの供試材が適用成分 範囲を満足していないためと考えられる。

Finklerと Schirra ${ }^{5}$ は，8〜14 mass\% Crを含有した鋼の連 続冷却変態線罒を調べる中で, 次のような $M_{s}$ 点予測式を 提案している。

$$
\begin{aligned}
M_{s}\left({ }^{\circ} \mathrm{C}\right)= & 635-474[\mathrm{C}+0.86(\mathrm{~N}-0.15(\mathrm{Nb}+\mathrm{Zr})) \\
& -0.066(T a+H f)]-(17 \mathrm{Cr}+33 \mathrm{Mn}+21 \mathrm{Mo} \\
& +17 \mathrm{Ni}+39 \mathrm{~V}+11 \mathrm{~W})(\operatorname{mass} \%) \cdots \cdots \ldots \ldots . . .
\end{aligned}
$$




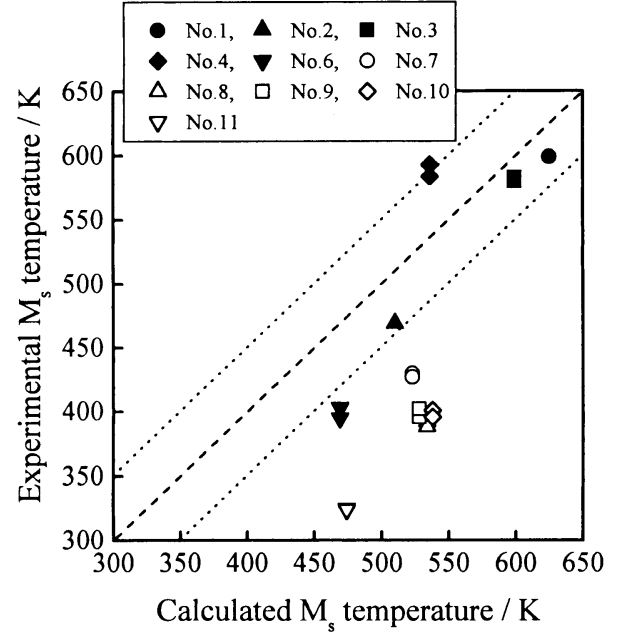

Fig. 4. Comparison between the $M_{\mathrm{s}}$ temperature calculated by Finkler et al. model and the experimental $M_{s}$ temperature.

この式は, Stevenと Haynesが提案した低合金鋼の $M_{s}$ 点 予測式に，炭窒化物形成元素 $(\mathrm{Nb}, \mathrm{Zr}, \mathrm{Ta}, \mathrm{Hf})$ およびV, Wの 項を追加したかたちになっている。また，この式の適用成 分範囲は 8 14 mass $\% \mathrm{Cr}, \sim 1$ at $\% \mathrm{C}, \mathrm{Mn}, \mathrm{Ni}, \mathrm{Mo}, \mathrm{W}, \mathrm{V}$ として いる。本実験結果とこの Finkler et al.のモデルによる計算 結果を比較して Fig. 4 に示す。供試材 No. 1 4のCr系ステ ンレス鋼においては，適用成分範囲をほぼ満足しているこ とから，計算により妥当な予測がなされている。一方，Ni が添加されている供試材 No. 6および Ni, Cuなどが添加さ れている供試材No. 7 11においては, 計算值が実測值に 比べて 60〜150K高くなっている。これは $(2)$ 式に考慮さ れていないCu濃度の影響および $\mathrm{Ni}, \mathrm{Mo}$ 濃度などが適用成 分範囲外にあることによるものと考えられる。

以上2つのモデルのほか，実験にもとづいて提案されて いるいくつかの $M_{s}$ 点予測モデル 6.7)を用いて, 本実験結果 と計算結果の比較を行った。しかしながら，すべての供試 材に対して，満足いく対応関係を与える予測式はなかった。 これらの結果は, 実験に基づいて提案されている $M_{s}$ 点予 測式は，その適用が特定の合金系で，かつ狭い成分範囲に 限定されているため，汎用性に乏しいことを示している。

\section{$4 \cdot 2$ Ghosh とOIsonのモデル}

GhoshとOlson ${ }^{12)} は$ ，マルテンサイト相生成に伴って発 生するひずみエネルギーと界面エネルギ一，さらに界面移 動に対する各固溶合金元素の固溶強化効果の総和により, マルテンサイト変態開始のための臨界駆動力 $\Delta G M_{s}\left(M_{s}\right.$ 点に おけるフェライト相とオーステナイト相の自由エネルギー 差)が，次式で与えられることを提案している。

$$
\begin{aligned}
-\Delta G_{M_{s}}= & K_{1}+\sqrt{\sum_{i}\left(K_{\mu}^{i} X_{i}^{0.5}\right)^{2}}+\sqrt{\sum_{j}\left(K_{\mu}^{j} X_{j}^{0.5}\right)^{2}} \\
& +\sqrt{\sum_{k}\left(K_{\mu}^{k} X_{k}^{0.5}\right)^{2}}+K_{\mu}^{\mathrm{Co}} X_{\mathrm{Co}}^{0.5} \ldots \ldots \ldots \ldots \ldots . . . . .
\end{aligned}
$$

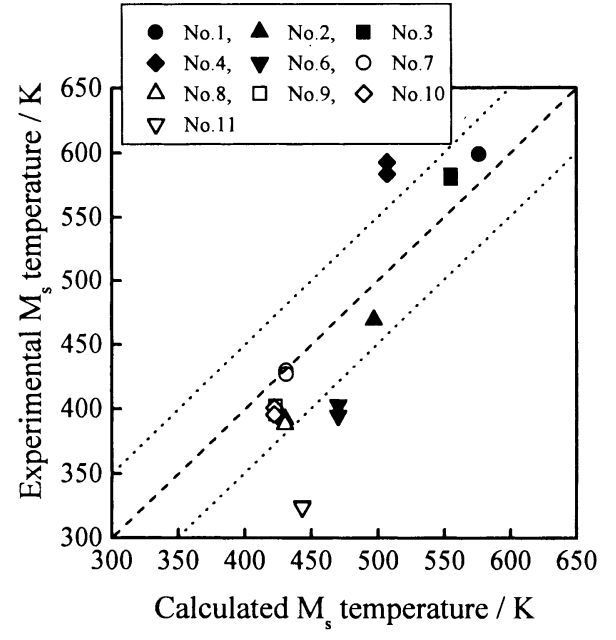

Fig. 5. Comparison between the $M$, temperature calculated by Ghosh et al. model and the experimental $M_{s}$ temperature.

ここで, $i=\mathrm{C}, \mathrm{N}, j=\mathrm{Cr}, \mathrm{Mn}, \mathrm{Mo}, \mathrm{Nb}, \mathrm{Si}, \mathrm{Ti}, \mathrm{V}, k=\mathrm{Al}, \mathrm{Cu}, \mathrm{Ni}$. Wであり， $X_{i}, X_{j}, X_{k}, X_{\mathrm{Co}}$ は各合金組成の mol\%を表してい る。この(3)式に, 本研究に関連する合金元素の定数項を 代入して書き下すと, 次式が得られる。

$$
\begin{aligned}
& -\Delta G_{M_{\mathrm{v}}}=1010+\sqrt{\left(4009 X_{\mathrm{C}}^{0.5}\right)^{2}+\left(3097 X_{\mathrm{N}}^{0.5}\right)^{2}} \\
& +\sqrt{\left(1868 X_{\mathrm{Cr}}^{0.5}\right)^{2}+\left(1980 X_{\mathrm{Mn}}^{0.5}\right)^{2}+\left(1418 X_{\mathrm{Mo}}^{0.5}\right)^{2}} \\
& +\left(1653 X_{\mathrm{Nb}}^{0.5}\right)^{2}+\left(1879 X_{\mathrm{Si}}^{0.5}\right)^{2} \\
& +\sqrt{\left(280 X_{\mathrm{Ai}}^{0.5}\right)^{2}+\left(752 X_{\mathrm{Cu}}^{0.5}\right)^{2}+\left(172 X_{\mathrm{Ni}}^{0.5}\right)^{2}}
\end{aligned}
$$

この式により，ある合金組成の鋼の臨界駆動力 $\Delta G M_{s}$ が算 出される。そして，熱力学計算ソフトを利用することによ り，温度に対するフェライト相とオーステナイト相の自由 エネルギー差 $\Delta G_{b c c-f c c}$ を計算し，これが $\Delta G M_{s}$ と一致する温 度をその鋼の $M_{s}$ 点として推定することができる。このモ デルには14種類の合金元素の影響が考慮されているほか， 明確な適用成分範囲の限定もなく，実験に基づく予測式の 検証で指摘された問題はない。ただし、このモデル ではすべての添加元素がオーステナイト相中に固溶し かつ非等温変態によりマルテンサイト相が形成されるこ とが前提条件となっている。このモデルに基づいて算出 した $M_{s}$ 点と本研究の実測值の関係を Fig. 5 に示す。ここ で, $\Delta G_{b c c-f c c}$ の計算には熱力学計算ソフトThermo-Calc ${ }^{18}$ (SSOLデータベース)を用いた。計算值は実験值とよく刘 㐫して打り，No. 4, 6, 11 を除き, Ghosh et al.が示したと扎 り $40 \mathrm{~K}$ の精度で予測できていることがわかる。

さらにGhosh et al.は, Fe-Cr-C系において, (3)式の第 3 項に含まれる $\mathrm{Cr}$ の項を第 2 項に移項して $\Delta G M_{*}$ を算出する 


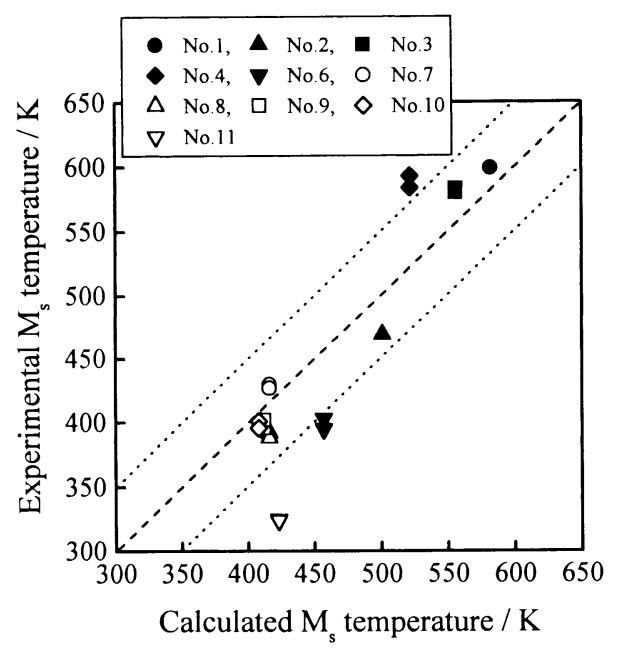

Fig. 6. Comparison between the $M_{\text {s }}$ temperature calculated by Eichelman et al. model modified for $\mathrm{Fe}-\mathrm{Cr}-\mathrm{C}$ system and the experimental $M_{s}$ temperature.

ことにより，より適切な予測ができるとしている。ステン レス鋼は基本的に $\mathrm{Fe}-\mathrm{Cr}$ 系であることから，この指摘に従 つて同様な計算を行った。その結果をFig. 6に示す。Fig. 5 と Fig. 6を比較した場合, 若干ではあるが, 計算值と実測 值が近づく傾向が忍められる。

以上の結果から, Ghosh et al.により提案された $M_{v}$ 点予 測モデルは，実用のマルテンサイト系ステンレス鋼に対し て，ある程度の汎用性をもっていると結論づけられる。

\section{$4 \cdot 3$ GhoshとOIsonのモデルによる計算值と実測値の 相違について}

Fig. 5 およびFig. 6に示した結果から，供試材No. 4, 6, 11 において計算値と実測值に不一致が認められた。そこで, この原因について考察する。

供試材 No. 4 は SUS420J2 相当鋼であり, $M_{s}$ 点が求めら れた供試材の中で，最も高いC 濃度 $(0.300$ mass\%) を有す る。このように高いC濃度を有するステンレス鋼において は，焼入れ前処理条件やオーステナイト化条件により，炭 化物の残留状態が変化するため, $100 \mathrm{~K}$ 以上の広い温度範 囲で $M_{s}$ 点が変動することが知られている ${ }^{199}$ 。本供試材に おいても, Fig. 2(a)で示したように, $M_{s}$ 点測定後の試料中 に $\mathrm{Cr}$ 系炭化物の残留が認められている。炭化物の残留は,

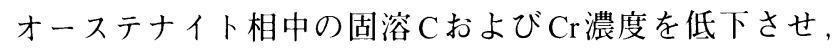
その結果 $M_{s}$ 点の上昇を招く。Fig. 5 おびFig. 6において， No. 4 の実測值が計算值より $80 \mathrm{~K}$ 程度高い原因は, この炭 化物の残留に起因するものと考えられる。また, 本研究で は, SUS630系析出硬化型ステンレス鋼における Nb系炭化 物の影響を考察するため，Cおよび $\mathrm{Nb}$ 濃度の異なる供試 材No. 7 10を準備し，実験を進めてきた。しかしながら， Fig. 2(b)で示したように Nb系炭化物の析出量が少ないた め，その影響は顕著ではなかった。またそそのために SUS630系において，計算值と実測值の間にずれが生じな かったものと考えられる。

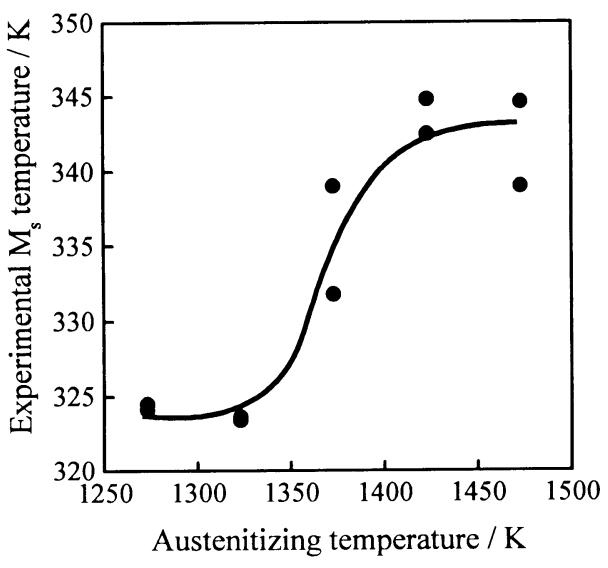

Fig. 7. Effect of austenitizing tenperature on experimental $M_{s}$ temperature of specimen No. 11. Specimens were austenitized at indicated temperature and then air cooled. After that, $M$ temperature of those specimens were measured with air cooling from $1273 \mathrm{~K}$.

供試材No. 11 は残留オーステナイト含有型の析出硬化ス テンレス鋼であり, 電気抵抗測定後の組織観察から, 炭化 物や $\delta$ フェライト相などの第2 相は観察されなかった。こ の点では, Ghosh et al.のモデルの適用は妥当であると考え られる。しかし実際には, 実測值は計算值より100Kも低

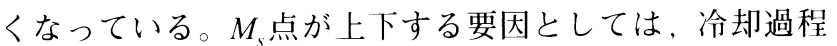
におけるオーステナイトの安定化や結唱粒径の影響などが 挙げられる。しかしながら，No.11はC, N濃度が低いこと から，冷却過程に扔いてオーステナイトの安定化が生じて いるとは考えにくい。一方，結晶粒径の影響については， 以前より多くの報告 ${ }^{20-221}$ があり，興味深いところである。 そこで，この点を検討するために次のような実験を行っ た。

供試材No. 11において, 前処理条件を1273〜1473Kの間 で変化させ，1.2 ks 空冷処理を行った後，電気抵抗測定装 置により温度 $T_{1}(1273 \mathrm{~K}) に て 1.2 \mathrm{ks}$ 空冷の一定条件のもと， $M_{\mathrm{s}}$ 点の測定を実施した。その結果をFig. 7にまとめる。こ

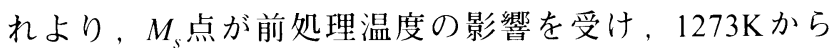
$1473 \mathrm{~K}$ の間で $20 \mathrm{~K}$ 程度上昇していることがわかる。Fig. 8 に $M_{s}$ 点測定後の試料の光学顕微鏡観察結果を示す。本供 試材はエッチングによる旧オーステナイト粒界の現出が難 しく，正確な結晶粒径の測定はできなかったが, Fig. 8か ら旧オーステナイト粒径は， $1273 \mathrm{~K}$ 前处理材で $20 \mu \mathrm{m}$ 程度, $1473 \mathrm{~K}$ 前処理材で $120 \mu \mathrm{m}$ 程度になっていると判断される。 すなわち, これらの結果は, No. 11の $M_{s}$ 点に対する結晶 粒径依存性を明らかにしたものであり，大変に興味深い。 さらに,これまでのいくつかの報告 ${ }^{23.24)}$ から推察すると， このNo. 11 の組成付近に扔いて，等温マルテンサイト変態 の生じる可能性が高いことが予測される。しかしながら，

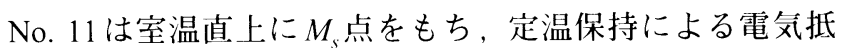
抗測定が困難であるため，この点を明らかにすることはで きなかった。これらのことから, Ghosh et al.のモデルでは 


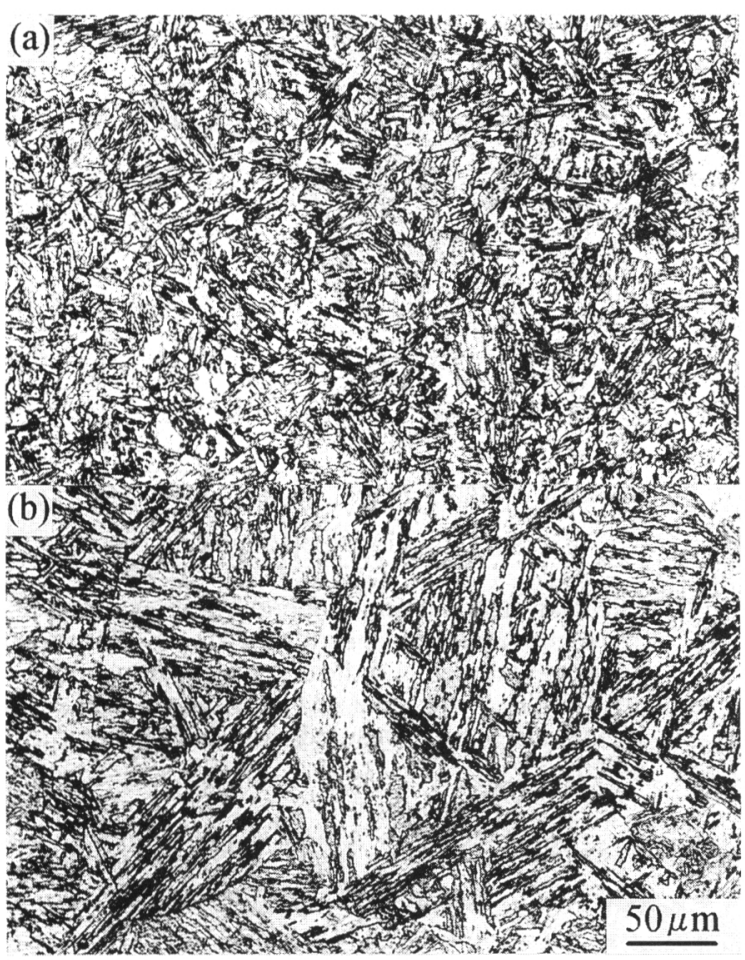

Fig. 8. Optical micrographs of specimen No. 11 austenitized at (a) $1273 \mathrm{~K}$ and (b) $1473 \mathrm{~K}$.

考慮されていない $M_{s}$ 点の結晶粒径依存性や等温マルテン サイト変態の影響が, 実測された $M_{s}$ 点に現れているため, 計算值と実測值の間に大きな不一致が現れたものと推察さ れる。

これまでは, Ghosh et al.のモデルにより妥当な $M_{s}$ 点予 測ができるということを前提に議論を進めてきた。このモ デルによる計算が正しく実行されか否かは, 熱力学計算ソ フトにより評価されているオーステナイト相扰よびフェラ イト相の自由エネルギーが，多成分系において正しく与え られているか否かに大きく依存している。しかも，本研究 で用いた供試材は，高合金のステンレス鋼であり， $M_{s}$ 点 が比較的低温域に存在するため, 自由エネルギーの評価が 適切であるか否かが懸念される。垁際， $\mathrm{Fe}-\mathrm{Cr}-\mathrm{Mn}-\mathrm{N}$ 系で は，Mn濃度に依存して計算值と実測值の間に䛊差が現れ るという指摘もある ${ }^{15)}$ 。その意味では，先に考察を加えた 供試材 No. 11 や 0.98 mass \% Mn 含有する供試材 No. 6な どでは, 自由エネルギーの評価が不十分であるために, 計 算值と実測值の間に大きな差が現れたとも考えられる。

\section{5. 結言}

本研究では, 汎用のマルテンサイト系ステンレス鋼6種 類打よびマルテンサイト系析出硬化型ステンレス鋼 5 種類 を用いて，従来提案されている $M_{s}$ 点予測式およびGhosh とOlsonのモデルにより導かれる予測 $M_{s}$ 点と垁測值の比較 を行い, モデルの有効性を検証し，以下の結論を得た。

(1) Cr系ステンレス龬において，Cr濃度の低下および C 濃度が上昇により，オーステナイト相とマルテンサイト 相の電気抵抗の差は小さくなる。そのため, 合金系によっ ては電気抵抗測定による $M_{s}$ 点の実測は不可能である

（2）実験結果に基づいて提案されている $M_{s}$ 点予測式 は，考慮されている合金元素の種類やその適用成分範井が 限られているため, 汎用性にそしい

(3) Ghosh とOlsonにより提案された $M_{s}$ 点予測モデル は,、マルテンサイト系ステンレス鋼に対して，一部を除き。 かなり有用である

\section{（4）供試材No. 11 は，M点の結晶粒径依存性を示す}

\section{文献}

1 ) C.Y.Kung and J.J.Rayment: Metall. Trans. A, 13A (1982), 328

2 ) W.G.Vermeulen, P.F.Morris, A.P.de Weijer and S.van der Zwaag: Ironmaking Steelmaking, 23 (1996), 433.

3 ) N.Murai and T.Tsumura: Tetsu-to-Hagané, 84 (1998), 446.

4 ) G.H.Eichelman, Jr. and F.C.Hull: Trans. Am Soc. Met., 45 (1953), 77.

5 ) H.Finkler and M.Schirra: Steel Res., 67 (1996), 328.

6 ) U.R.Lenel and B.R.Knott: Metall. Trans. A, 18A (1987), 767.

7 ) M.Tanino and C.M.Liu: Proc. Int. Conf. on Microstructures and Function of Materials (ICMFM 96), ed. by N.Igata et al., Science University of Tokyo, Tokyo, (1996), 29.

8 ） ステンレス鋼便覧(第7版)，長谷川正義監修，日刊工業新聞社。 東京, (1979), 59 .

9) V.Raghavan and D.P.Antia: Metall. Trans. A, 27A (1996), 1127.

10) H.K.D.H.Bhadeshia: Met. Sci., 15 (1981), 178

11) K.Ishida: J. Alloys Comp., 220 (1995), 126

12) G.Ghosh and G.B.Olson: Acta Metall. Mater., 42 (1994), 3361

13) H.Ikeda, T.Isomoto and G.Abe: Sanyo Tech. Rep., 1 (1994), 28

14) T.Cool and H.K.D.H.Bhadeshia: Mater. Sci. Technol., 12 (1996), 40.

15) J.Kunze and B.Beyer: Z. Metallkd., 88 (1997), 722.

16) H.Nakagawa, H.Yokota and T.Miyazaki: Tetsu-to-Hagané, 84 (1998), 381 .

17) T.Shimizu, T.Tateyama and M.Okabe: Denki Seiko, 67 (1996), 87.

18) B.Sundman, B.Jansson and J.O.Anderson: Calphad, 9 (1985), 153

19) N.Hirose and S.Yamamoto: Netsu Shori, 27 (1987), 17.

20) M.Umemoto and W.S.Owen: Metall. Mater. Trans., 5 (1974), 2041.

21) M.Fujikura and T.Kato: Tetsu-to-Hagané, 64 (1978), 1179.

22) K.Takeuchi, S.Sugiura, Y.Katayama, T.Inui and J.Sunakawa: Materia Jpn., 36 (1997), 358.

23) Y.Imai and M.Izumiyama: J. Jpn. Inst. Met., 27 (1963), 170 24) K.Ito, S.Isobe and K.Shinohara: Denki Seiko, 45 (1974), 83. 